\title{
A (Super) Heroic Vision of Leader Self
}

\author{
Genie Bingham Linn \\ University of Texas at Tyler \\ glinn@uttyler.edu
}

\begin{abstract}
This study leads the reader on a learning journey with the heroic metaphors derived from heroic myths of today's pop culture to the views shared by aspiring administrators. Viewing the students' leadership vision of self as hero provided insight to guiding students in their personal leadership journey. By naming and describing self as hero, future administrators examined and then revised their own mental models for leadership by translating pop culture characters from Spiderman to McGyver to their own heroic metaphor and vision of school leaders.
\end{abstract}

\section{Introduction}

Our desire for heroes in life is evident in the entertainment industry. From Star Wars to Harry Potter, we crave the adventures of the hero. Children pretend with plastic light sabers and magic wands to right wrongs and save the world. Even the military marketing strategists have depicted the modern soldier in a heroic picture of a sword-wielding, dragon-slaying warrior. From the popular video game Guitar Hero to the NBC series Heroes, we seem to hunger for heroes with extraordinary qualities or most importantly, those who exemplify moral leadership (Linn, 2006; 2007).

Where are the heroes for educators? What heroic visions have we created for ourselves? We must look within and beyond ourselves in hope of what we could become.

Bruner (2002) asserts that we are constantly in the process of creating the narrative of self, becoming the "hero" to address the situations before us. School leaders have been given professional metaphors to frame their stories by researchers and scholars, but it is equally important for each leader to identify a personal story, a personal vision of self as hero.

According to Cherry and Speigel (2006), storytelling and use of metaphor provide a way to deep understanding of moral leadership. Metaphors have the power "to 
shape the pattern of our ideas and the character of our lives" (Ivie, 2005, p. 1). By accessing this creative power, professors and scholars of educational administration can guide future leaders to navigate the moral and ethical challenges in schools by helping them to frame a picture of self within the role of administrator. This work explores the heroic visions shared by aspiring educational leaders. Viewing the students' leadership vision of self as hero provides insight to instructors who are guiding them in their personal leadership journey.

In the effort to prepare principals and school administrators, exemplary university programs influence administrative initiates in three ways: what they learn, what they believe, and what their commitments are (Darling-Hammond, Meyerson, LaPointe, \& Orr, 2010). They suggest that "without these initial influences, programs are unlikely to affect subsequent leadership practices" (p. 105). Educational administration programs can deliver information and increase knowledge, but it is only by influencing belief and commitment that actions are shaped. For it is not what I know that affects my behavior, it is what I believe. Senge's (1990) significant twentieth century study of the learning organization placed strong emphasis on the individual examination and recognition of one's own mental models that ultimately shape belief and consequent behaviors as a critical component for learning and change.

The heroic metaphor activity tapped into the context of pop culture that provides a strong learning connection for today's students as described by Williams and McClure (2010). This teaching strategy is only one way professors can guide future administrators in reflective practice to unveil the often unrecognized mental models that affect how they will one day lead. The heroic metaphor based on pop culture heroes of today becomes a tangible element of belief and commitment that the individual can examine from all sides to come to an understanding of self and others through the lens of "Who am I as leader."

\section{Reflection and the Heroic Metaphor}

What is a hero? The dictionary defines hero as someone admired for qualities of great courage and quite literally, a defender and protector. The hero in a story can simply be the protagonist or central character. Heroes from classical Greek mythology to the pop culture heroes of today have served as an ideal or role model. A provocative essay by Chatterji (1985) asserted that heroes serve as a symbol of self. In English's (2008) discourse on leadership as an art, the assertion is made that leaders construct a public self to portray a character of leadership. It is a conscious and deliberate creation to be who is needed for the organization and its stakeholders. The public self establishes "who I am" for others to see. 
Who am I? Who am I as leader? As a leader the complexity of these questions calls for the use of a heroic metaphor in order to "deepen our understanding and knowledge" (Brown \& Moffett, 1999, p. 32). The metaphor serves as a link to help us cross the chasm from known to unknown. The use of a heroic metaphor makes tangible the intangible to illustrate a model or ideal. They note it is a quick and powerful shortcut to communicate a complex idea, and in fact, can shape our mental models. Indeed, it becomes imperative for the leader or aspiring leader to engage in the act of examining one's own mental model of self as leader.

Who am I as leader? Wisdom dictates that leaders examine thoughts, actions, and beliefs. According to English (2008), "Human growth, especially in leadership, is about the discovery of self" (p. 25). Therefore, wise leaders will engage in reflection and seek self-knowledge to lead in today's world.

\section{Using Complex Heroic Metaphors}

Reflection and critical thinking are required to learn through complex heroic metaphors. Heroes are an extension of myth that serves as a base for human thinking (Campbell, 1968). Mythology, and consequently heroes, has always been a guide for understanding the mysteries of the world as they present the universal themes of human experiences (Ivie, 2003). This study leads the reader on a learning journey with the heroic metaphors derived from pop culture heroic myths to the views shared by aspiring administrators.

Educators have been given stories to frame the work; but, it is equally important for each leader to examine a personal story, a personal vision of self, or hero to emulate. As an introductory activity, students in an educational leadership course shared a fictional hero with whom they identified. The light-hearted ice breaker activity quickly became an occasion for students to reveal their passionate and insightful perspective of the heroic nature of school leadership. These future administrators easily translated characters from Spiderman to McGyver to their personal heroic metaphor and vision of school leaders.

This study is born from the responses of these aspiring administrators as they explored a personal vision of self as hero. Using the process of content analysis, the responses have been analyzed and catalogued into three themes: traditional comic superheroes, uncommon heroes of ordinary people, and nontraditional comic heroes. Traditional comic superheroes include Superman, Batman, and Spiderman. It is not surprising that these god-like heroes with super strength and powers were chosen by $25 \%$ of the participants. Interestingly, the reasons given by the future administrators had much to say about the individual character of the 
participants. Superman was selected by one male participant because of Superman's strong moral compass and his ability to transform himself to meet the challenges before him. A female student chose Superman because of the extraordinary strength that allowed him to rescue those in need since "he always rescues the innocent bystander." Batman was chosen by another male student because he is highly respected and a relentless problem solver who works with others and is an innovator with technology who "always used the best gadgets around." The following is an excerpt from a student response that exemplifies this category:

- $\quad$ The fictional hero that I best relate to is Superman. Superman is a character that is human, yet has the ability to transform into a superhero and then is able to change the culture around him. Superman saves the world, positively impacts others, and destroys evil while ultimately fighting for "truth, justice and the American way." There are three main reasons that I chose Superman: 1) he was imbued with a strong moral compass, 2) he served as a role model, and 3) he was able to transform...Superman is an average individual who can transform into a "super hero" when the need arises. He is always there to save the day when trouble lurks. I know there will be many instances where I have to transform myself from an everyday individual into someone with super powers. An effective leader is able to transform when the need arises to handle complex situations.

Uncommon heroes of ordinary people included fictional characters like, Clint Eastman's Dirty Harry, Patricia Cornwall's Kay Scarpetta, Jessica Fletcher from Murder She Wrote, Maximus from The Gladiator, Angus McGyver from McGyver, and finally, Maria from the Sound of Music. Fifty percent of the students chose these uncommon heroes in spite of their human weaknesses because they were practical, hardworking problem solvers who never gave up. Although their human frailties often caused problems, their courage and strong belief in justice for others meant they never quit fighting for what is right. The following segment is from a student who identified with Dirty Harry:

- Dirty Harry causes me to stand and yell, "Way to go, Harry! You get 'em!'... Dirty Harry exudes confidence, possesses a strong sense of right and wrong, takes a no-nonsense approach despite the odds against him, and most of all Dirty Harry get the job done...Dirty Harry is not perfect and has some serious personality traits that he would need to work on, but he still has characteristics that an educational leader should strive to emulate.

Nontraditional comic heroes included Jerry Spinelli's Maniac McGee, Bob the Tomato from Veggie Tales, Professor McGonagall and Hermione from Harry 
Potter, Princess Fiona from Shrek, and Sesame Street's Super Grover. These characters exhibited loyalty and courage. In addition, students pointed to the heroes' willingness to take risks while working for a cause greater than self. Professor McGonagall was noted for her commitment to students' welfare and safety, as well as academic growth. Bob the Tomato was a very interesting choice for one student as seen in the following excerpt:

- I honestly was trying to choose a character that no one else would choose as their favorite hero. I think this enlightens others about my leadership style. I am considered a unique leader, one who is not afraid to go out on a limb and be different. I am not afraid to be innovative and look to "push the envelope." I think things can be done better than they have in the past and know that I will have to be open to new ideas and willing to take a chance on my future campus.

Who am I now? Who do I want to become? This student is developing a public self-image for his future role as a principal. According to English (2008), within the art of leadership there is a "purposive construction of self" (p. 5). While comparing himself to Bob the Tomato, this student is mentally preparing his hero self for an important position.

Leading the students through this activity "intentionalized" what we often do unintentionally. Refection and writing are powerful tools for personal change and professional growth (Bolton, 2005). By naming and describing self as hero in a class activity, students examined and then revised their own mental models for leadership.

\section{Conclusion}

The school leader must know self in order to lead others wisely. Since knowing self is a key to deep understanding of others (Brunner, 1994), an educational leader should seek to know self in order to understand the school stakeholders. Imagining and reflecting upon self as leader through heroic metaphor provides a creative framework for envisioning successful school leadership. Professors of educational administration aim at "getting to the heart of moral purposes and innate dispositions" (Cherry \& Spiegal, 2006, p. 70) where belief and commitment emanate, and to do so "requires an opening of new passages to insight and new modes of expression" (p. 70). Envisioning the heroic metaphors of self can be one passageway to school leadership development. 


\section{References}

Bolton, G. (2005). Reflective practice: Writing \& professional development $\left(2^{\text {nd }}\right.$ ed.). Thousand Oaks, CA: Sage.

Brown, J. L., \& Moffett, C. A. (1999). The hero's journey: How educators can transform schools and improve learning. Alexandria, VA: ASCD.

Brunner, D. D. (1994). Inquiry and reflection: Framing narrative practice in education. Albany, NY: State University Press.

Bruner, J. (2002). Making stories: Law, literature, life. Cambridge: Harvard University Press.

Chatterji, P. (1985). The voyage of the hero: The self and the other in one narrative tradition. Contributions to Indian Sociology, (19), 95-114.

Cherry, D., \& Speigel, J. (2006). Leadership, myth, \& metaphor: Finding common ground to guide effective school change. Thousand Oaks, CA: Corwin Press.

Darling-Hammond, L., Meyerson, D., LaPointe, M., \& Orr, M. T. (2010). Preparing principals for a changing world: Lessons from effective school leadership programs. San Francisco: Jossey-Bass.

English, F. W. (2008). The art of educational leadership: Balancing performance and accountability. Los Angeles: Sage.

Ivie, S. (2003). On the wings of a metaphor. San Francisco: Caddo Gap Press.

Linn, G. B. (2006). Reflections on being a leader: Looking through the lens of legend and myth. Sandra Harris, Betty Alford \& Julia Ballenger (Eds.), Women as school executives. Leadership: A bridge to ourselves. Texas Council of School Women Executives.

Linn, G. B., Sherman, R., Sherman, \& Gill, P. B. (2007). Making meaning of educational leadership: The principalship in metaphor. NASSP Bulletin 21(2), 161-171.

Senge, P. (1990). The fifth discipline: The art and practice of the learning organization. New York: Doubleday. 
William, J., \& McClure, M. (2010). The effects of teaching methods in leadership knowledge retention: An experimental design of lecture, experiential, and public pedagogy. Journal of Leadership Education, 9(2), 86-100.

Retrieved from:

http://bigcat.fhsu.edu/jole/issues/JOLE_9_2/JOLE_9_2.pdf 


\section{Author Biography}

Genie Bingham Linn is an associate professor in the Department of Educational Leadership and Policy Studies at the University of Texas at Tyler. Genie teaches graduate students in the master's program who are aspiring principals. 